\title{
THE EU CHARTER OF FUNDAMENTAL RIGHTS AND THE SUBSISTING COMMITMENTS OF EU MEMBER STATES UNDER THE EUROPEAN CONVENTION ON HUMAN RIGHTS: MORE VARIABLE GEOMETRY
}

\begin{abstract}
Robert Lane*
Summary: The product of discrete sources and strands, the protection of fundamental rights in Europe has now begun to knit together. The difficulties spring less from widely varying views of what fundamental rights ought to be than from their being played out upon different planes and to different purpose: pan-Europe by virtue of the European Convention on Human Rights, and pan-European Union with its economic (Community) emphasis and partially common law approach combined now with a codified Charter of Fundamental Rights. Perhaps more contentious is the institutional mechanisms by which rights are to be judicially protected, the relatively coherent Convention system and the quasi-appellate jurisdiction of the Court of Human Rights through the right of individual petition, and the Community/Union system which exists in a different dimension yet embraces (or purports to embrace), but is not (yet) formally married to, the Convention - but to which, it is important to remember, the member states are signatory and still subject. The two courts at the heart of this protection, the Court of Human Rights in Strasbourg and the Court of Justice in Luxembourg, have moved slowly into a closer embrace, but each remains subject still to the peculiarities of its jurisdiction, conscious of the practical limits to its authority and wary of the risks of over-confidence and extending itself too far. Recent developments in their case law, brought about especially by the growth of Union activities which escape Luxembourg scrutiny, have brought issues to a head and produced both robustness and deference from Strasbourg. At the same time events are moving on as life is breathed back into the Constitution for Europe, which had proposed one solution, by the draft Reform Treaty, which proposes another. It also goes down the road of yet more variable geometry, a device all too easy as a means of earning agreement in the political arena but often leaving legal chaos in its wake.
\end{abstract}

There has been a long, slow, and sometimes reluctant development of fundamental rights protection within the European Community

\footnotetext{
* Robert Lane, School of Law, Edinburgh University, robert.lane@ed.ac.uk
} 
and, subsequently, the Union. Whilst by any standard a great deal has been achieved, it is still a work in progress. Recent judgments of both the Court of Justice ('Luxembourg') and the European Court of Human Rights ('Strasbourg') have now conspired to make the issues more complex still, giving heart to those who feared that we enjoyed inadequate levels of protection within the Union, yet at the same time not providing them unalloyed comfort.

What we are now witnessing is the development of multi-level or triangular protection - by Strasbourg, by Luxembourg and by national courts - for the implementation and protection of fundamental rights in the Union. It is what a recent President of the Court of Human Rights called 'détriplement fonctionnel', ${ }^{1}$ and it defies both easy definition and easy coordination. And it is a matter not just of overlapping jurisdiction but of overlapping and cross-fertilised substantive law, yet applied by the various courts in a manner which reflects their purpose and their legal culture.

There are a great many issues which come under the umbrella of the topic. The areas to be considered here are, first, the developments relating to the surviving obligations of the member states, as signatories of and parties to the European Convention, in the Community/Union context and the continuing application of the Convention and jurisdiction of the Court of Human Rights in the face of competing Union norms; and second, interwoven with the first, whether the Community and/or Union, although not party to it, have absorbed, or assumed, obligations under the Convention and, if so, how they might be enforced. Events recent and in train have added new variables to the equation which make jurisdiction détriplement now an oversimplification.

\section{Treaty norms}

There is a preliminary issue, sometimes overlooked, to be considered, which is the hierarchy of treaties in the Community/Union system, a function partly of public international law, partly of the Community treaties themselves. The Community, and subsequently the Union, were created by international treaties. Other than the breadth of the Community undertaking there was little in the (then) EEC Treaty to indicate a fundamental qualitative difference between it and most other international treaties - although those with eyes to see could perhaps have detected its many hints to that effect. It was not until van Gend en $\operatorname{Loos}^{2}$ that the

1 L Wildhaber, 'The Coordination of the Protection of Fundamental Rights in Europe', an address presented in Geneva, 8 September 2005.

2 Case 26/62 Algemene Transport- en Expeditie Onderneming van Gend en Loos v Nederlandse Administratie der Belastingen [1963] ECR 1. 
revolutionary nature of that Treaty, and the 'new legal order' it creates, began to become apparent. So the Court may now observe glibly that the Treaty is less a treaty, more a (quasi-)constitution: 'albeit concluded in the form of an international agreement, [it] none the less constitutes the constitutional charter of a Community based on the rule of law'. ${ }^{3}$ And whilst van Gend en Loos confirms the transfer of sovereignty to the Community ('for the benefit of which the states have limited their sovereign rights'), ${ }^{4}$ of course what the Community - still less the Union - is not is a federal or similar (and certainly not a legislative) union which would have assumed and extinguished the international personality of the member states. ${ }^{5}$ They remain subjects of international law and in principle bound by the treaty obligations into which they entered, unless those obligations are displaced in some manner consistent with international law.

For clarity, the Treaty provides that rights and obligations deriving from treaties between one or more member states on the one hand and one or more third countries on the other which existed prior to the entry into force of the Treaty (or, for accession member states, prior to the date of their accession) 'shall not be affected' by the Treaty. ${ }^{6}$ This is simply articulation of a principle recognised in international law, ${ }^{7}$ and in law generally, that a contractual obligation cannot be avoided by a party entering subsequently into a different obligation with an unconnected party which is inconsistent with the first:

[T] he purpose of that provision is to make it clear, in accordance with the principles of international law, that application of the EC Treaty does not affect the duty of the Member State concerned to

\footnotetext{
3 Opinion 1/91 Re the EEA Agreement [1991] ECR I-6079 para 21. In 1986 the Court had referred to judicial review of Community legislation for 'conformity with the basic constitutional charter, the Treaty'; Case 294/83 Parti Ecologiste 'Les Verts' v European Parliament [1986] ECR 1339 para 23. The Bundesverfassungsgericht attributed this quality to the Treaty as early as 1967 ('Der EWG-Vertrag stellt gewissermaßen die Verfassung dieser Gemeinschaft dar'); 18. Oktober 1967, BVerfGE 22, 293, 296.

4 Case 26/62 van Gend en Loos (n 2) 12.

5 This is not to touch upon the fraught subject of the international personality of the regional authorities of a federation, in particular the extent to which they may enter into treaties, a principle which, provided that the capacity is admitted in the federal constitution, has gained some recognition in international law; see Report of the International Law Commission to the General Assembly [1966] ILC Yearbook vol II 169, 191-192. See also draft Article 5(2) to what became the Vienna Convention on the Law of Treaties 1969 (n 7): 'Members of a federal union may possess capacity to conclude treaties if such capacity is admitted by the federal constitution and within the limits there laid down', which was ultimately repressed.

6 Art 307(1) EC Treaty.

7 Vienna Convention on the Law of Treaties 1969 (adopted 23 May 1969, entered into force 27 January 1980) 1155 UNTS 331 art 30; Harvard Law School, Research in International Law, III. Law of Treaties, Supplement to (1935) 29 AJIL 707, 1024.
} 
respect the rights of third countries under a prior agreement and to perform its obligations thereunder. ${ }^{8}$

The Treaty does however impose upon the member states an obligation to 'take all appropriate steps' to do away with any irregularities to which they give rise ('eliminate the incompatibilities established'). ${ }^{9}$ Presumably this extends to an obligation to denounce an inconsistent treaty obligation where that authority exists ${ }^{10}$ and, where it does not, to seek to negotiate its termination. If necessary the member states are to assist each other in this end and, where appropriate, adopt a common attitude. ${ }^{11} \mathrm{Ma}-$ terial amendment to a pre-existing treaty with a third country is deemed to be a new treaty, not enjoying the protection of article $307 .{ }^{12}$

Article 307 applies to bilateral or multilateral treaties with third countries but if multilateral and involving two or more member states it does not, as a general principle, apply as between or amongst them. ${ }^{13}$ The co-existence of the two apparently contradictory propositions was described elegantly by Sir Gerald Fitzmaurice thus:

Since anything that some of the parties to a treaty do inter se under another treaty is clearly res inter alios acta, it cannot in law result in any formal diminution of the obligation of these parties under the earlier treaty, or affect juridically the rights or position of other parties, which remain legally intact and subsisting, ${ }^{14}$

and less elegantly by the Court of Justice:

By virtue of the principles of international law, by assuming a new obligation which is incompatible with rights held under a prior treaty a state ipso facto gives up the exercise of these rights to the extent necessary for the performance of its new obligations. [...] In matters governed by the EEC Treaty, that Treaty takes precedence over

\footnotetext{
8 Case T-306/01 Yusuf v Council \& Commission [2005] ECR II-3533 para 236. The Court recognised this principle to operate from the other side of the fence, saying it would breach art 10 of the Treaty (as well as public international law) were a member state now to enter into an international commitment with a third country which would affect or alter the scope of Community rules; Case C-523/04 Commission v Netherlands (Open Skies) (ECJ 24 April 2007).

9 Art 307(2) EC Treaty.

10 See Case C-84/98 Commission v Portugal [2000] ECR I-5215; Case C-203/03 Commission v Austria [2005] ECR I-935.

11 Art 307(2) EC Treaty.

12 Case C-523/04 Open Skies (n 8).

13 Case 10/61 EEC Commission v Italy [1962] ECR 1; Case C-473/93 Commission v Luxembourg [1996] ECR I-3207; Case C-147/03 Commission v Austria [2005] ECR I-5969.

14 G Fitzmaurice, Third Report [on the Law of Treaties] [1958] ILC Yearbook vol. II 43.
} 
agreements concluded between Member States before its entry into force. ${ }^{15}$

In other words, the more recent (Community) obligations displace prior obligations of the member states inter se where the interests of third countries (or persons in third countries), of which it is the purpose of article 307 to protect, are not in issue. According to the Court of Justice, this 'cannot be criticized by third countries since [it] does not interfere with the rights held by third counties under agreements still in force'; ${ }^{16}$ it squares this construction with the text of article 307 by distinguishing between the 'rights' to which it refers as the rights of third countries and the 'obligations' which adhere to the member states. ${ }^{17}$

Now this is permitted in international law, but not without reservation; it is not permitted if it is forbidden by the provisions of the earlier treaty or if the latter treaty is so inconsistent with the general purpose of the earlier treaty as to be likely to frustrate it. ${ }^{18}$ Nor is it a rule applied universally even within Community law. Exempted from it are:

- the United Nations Charter, to which all member states save Germany were contracting parties prior to their Community/Union membership; ${ }^{19}$ the Court of Justice appears to accept the UN's own construct $^{20}$ that the Charter has priority over Community law even as amongst the member states simply as a function of the primacy accorded it within the hierarchy of public international law; ${ }^{21}$

- the treaties founding the Belgium-Luxembourg economic union $(\mathrm{BLEU})^{22}$ and the Benelux economic union, ${ }^{23}$ which are ring-fenced

15 Case 10/61 EEC Commission v Italy (n 13) 10.

16 Ibid 11.

17 Ibid 10; Case C-473/93 Commission v Luxembourg (n 13) per opinion of AG Léger para 163.

18 Harvard Law School (n 7) 1016.

19 The Federal Republic and the Democratic Republic were both admitted to the UN, following long and complex legal and political debate, only in 1973; UNGA Res 3050 (XXVIII) (18 September 1973). Membership of the Democratic Republic lapsed with its dissolution in 1990 .

20 See Charter of the United Nations art 103: 'In the event of a conflict between the obligations of the Members of the United Nations under the present Charter and their obligations under any other international agreement, their obligations under the present Charter shall prevail'.

21 Case T-306/01 Yusuf $v$ Council \& Commission [2005] ECR II-3533.

22 Convention établissant une Union économique entre le Grand-Duché de Luxembourg et la Belgique (adopted 25 July 1921, entered into force 1 May 1922) 9 LNTS 223; replaced in 2005 by Protocole portant modification de la Convention coordonnée instituant l'Union économique belgo-luxembourgeoise (adopted 18 December 2002, entered into force 16 January 2005) JO du G-D de Luxembourg du 17 juin 2004, 1515.

23 Traité instituant l'Union économique Benelux (adopted 5 February 1958, entered into force 1 November 1960) 381 UNTS 165, replacing the Benelux customs union (Convention 
from the application of the EC Treaty (it 'shall not preclude the existence or completion of [those] regional unions') insofar as 'the[ir] objectives [...] are not attained by the application of this Treaty'. ${ }^{24}$ Thus article 306 saves a BLEU and/or Benelux rule inconsistent with Community law if it pursues a legitimate objective of the union, serves a more advanced degree of integration than the equivalent Community rule ${ }^{25}$ and is necessary for that purpose; ${ }^{26}$

- the Euratom Treaty, from which the provisions of the EC Treaty 'shall not derogate'. ${ }^{27}$

In the same way the priority of the EC and Euratom Treaties themselves, present and future, is preserved over the Treaty on European Union, ${ }^{28}$ so long as the Community/Union constitutional structure subsists.

What was not clear, and has only recently been made clear(er), is the place within this scheme in which the European Convention on Human Rights, to which all member states were contracting parties prior to their Community/Union accession, ${ }^{29}$ finds itself. The public international law rule is relatively straightforward where a prior and a later treaty are concerned with the same, or a similar, subject matter. But the Community and the Convention exist on different planes; perhaps more accurately,

douanière néerlando-belgo-luxembourgeoise; adopted 5 September 1944, entered into force 1 January 1948) 32 UNTS 143.

24 Art 306 EC Treaty. The Open Skies rule that would leave the 1958 modification of Benelux and the 2002 modification of the BLEU unprotected from the full force of the Treaty (see $\mathrm{n}$ 8) does not apply (presumably) because art 306 ring-fences not the treaties creating the BLEU and the Benelux but 'these regional unions'. In the same way the Benelux Treaty (art 94(1)) permits derogation for the BLEU in terms almost identical, and the 1972 accession Treaty (art 48) permitted similar, if more limited and now spent, derogation from the EEC Treaty for obligations arising from the 1965 Free Trade Agreement between Ireland and the United Kingdom.

25 Case 105/83 [1984] Pakvries v Minister van Landbouw en Visserij [1984] ECR 2101; Case C-473/93 Commission v Luxembourg [1996] ECR I-3207.

26 Case 56/75 Elz $v$ Commission [1976] ECR 1097.

27 Art 305(2) EC Treaty. There is a similar saving provision for the ECSC Treaty in art 305(1) which is now spent. The latter disappeared in the Treaty establishing a Constitution for Europe, the former to be saved in the Euratom Treaty itself, as a new art 106a(3); presumably the Reform Treaty will make similar provision.

28 Art 47 Treaty on European Union (hereinafter TEU) ('[N]othing in this Treaty shall affect the Treaties establishing the European Communities or the subsequent Treaties and Acts modifying or supplementing them').

29 The exception is France, which although a founding member of the Council of Europe did not ratify the Convention until 1974; therefore, uniquely, for France the EEC Treaty is the prior treaty. This opens up the theoretical (although probably not material) possibility that the Convention may apply differently in France owing to any constraints placed upon it by Community (that is, EEC) law, but not by any material subsequent (post-1974) changes to it. 
the Convention exists on its own 2-dimensional plane, but Community law - and certainly Union law taken as a whole - occupy n-dimensional space, across which the former may cut at any number of interstices. There are further, qualitative differences: whilst the medium of the Convention is by necessity a compact between states, it speaks directly to individuals and their benefit, in a context of fundamental human rights, as against the state; the original EEC Treaty is an economic blueprint, any tangency with human rights not immediately apparent. Put differently, the Convention is primarily for the benefit of the individual properly so-called, and a trawl through the case law of the Court of Human Rights will confirm that it is the individual who most frequently calls upon its aid. As for Community law, the concern of directly effective Treaty rights is for the individual in its normal (if misleading) Community law sense of both natural and juridical person, and Luxembourg's meat and drink is his interests within the overriding imperative of building the common/internal market: van Gend en Loos may have been the vanguard in the wake of which all else follows, but van Gend en Loos was a naamloos venootschap, not a true individual. And the interests, and protection, of the true individual are in many respects different from that of a corporation. Added to this is the superior norm which human rights conventions may, or in the view of some ought to, occupy. The counter argument is a strict application of article 30 of the Vienna Convention, that the member states have displaced the operation of the Convention and replaced it with the Community's own system for the protection of human rights, at least where Community law applies. This would mean, if positing a Community standard which offers lesser protection than does the Convention, the higher standard applies to a citizen of the Union when exercising rights wholly unconnected with Community law; or, even more bizarrely, a Latvian, for example, enjoying greater (Convention) rights within the Community insofar as he is a subject of Community law prior to 2004 , his nationality entitling him to the continuing protection of the Convention by article 307 of the Treaty, but that protection being downgraded immediately upon accession to the Union.

\section{Fundamental Rights in Community/Union Law}

That the protection of fundamental rights forms part of Community law is no longer seriously in doubt. Whilst there is spirited (and perhaps inevitable) debate as to its extent, and serious criticism from some quarters that what the Court of Justice says and what the Court does are, in this context, two very different things, ${ }^{30}$ it is now fully established in a

30 See in particular J Coppell \& A O'Neill, 'The European Court of Justice: Taking Rights Seriously?' (1992) 29 CML Rev 669. This article engendered a spirited riposte in WHH Weiler \& N Lockhart, “'Taking Rights Seriously” Seriously: The European Court and its Fundamental Rights Jurisprudence' (1995) 32 CML Rev 51 and 579. 
consistent line of case law that respect for fundamental (human) rights forms a general principle of Community law, and, in the pantheon of the general principles of Community law, it is primus inter pares.

But it is equally well known that it was not always so. The original Treaty made no mention of fundamental human rights and the Court of Justice originally repelled any argument that Community action ought to be made subject to them ${ }^{31}$ - a view sometimes attributed now to the "sins of youth'. From the early 1970s, and it is thought at least partially in response to fear of rebellion from the German Bundesverfassungsgericht, the Court of Justice has held consistently that 'respect for fundamental human rights forms an integral part of the general principles of law protected by the Court of Justice'. ${ }^{32}$ As a result we are now at a stage in which the Treaty on European Union can say: 'The Union is founded on the principles of liberty, democracy, respect for human rights and fundamental freedoms, and the rule of law, principles which are common to the Member States'. ${ }^{33}$ As they are not (yet) in the Treaty, the question then arises as to where these human rights and fundamental freedoms come from.

At the moment the Court recognises three distinct but intertwined sources of fundamental rights law, ${ }^{34}$ as follows:

\section{a) The constitutional traditions common to the member states}

This was the first source of fundamental rights to be recognised by the Court of Justice. But as an operational body of law they are very difficult to identify. The traditions run the spectrum from paragraphs 1 to 20 of the German Basic Law, a stringent catalogue of rights which forms the highest constitutional norm in the Federal Republic, to the rights of the subject which are recognised by the common law of England but which are written nowhere, are not (and cannot be) constitutionally entrenched, ${ }^{35}$ and survive only at the whim of a government and Parliament

31 Case 1/58 Stork $v$ High Authority [1959] ECR 17; Cases 36 etc/59 Präsident RuhrkohlenVerkaufsgesellschaft $v$ High Authority [1960] ECR 423.

32 Case 11/70 Internationale Handelsgesellschaft mbH $v$ Einfuhr- und Vorratsstelle für Getreide und Futtermittel [1970] ECR 1125 para 4.

33 Art 6(1) TEU.

34 For a discussion of this complex approach to sources of human rights, see V Skouris, 'Introducing a Binding Bill of Rights for the European Union: Can Three Parallel Systems of Protection of Human Rights Co-exist Harmoniously?' (December 2004) Hellenic Review of European Law 3.

35 A laudable attempt was made with the Human Rights Act 1998 which incorporates the European Convention into UK law. However it does not entrench the Convention, rather it obliges public authorities to act in a manner consistent with it (s 6), requires the courts to interpret national law 'so far as it is possible to do so' in a manner compatible with Convention rights (s 3), and, if that is not possible, to make a 'declaration of incompatibility' (s 
of the day; and everything in between. From these the Court claims to look to, and distil, a high standard of protection rather than the lowest common denominator, but it is a complex undertaking and allows the Court significant discretion.

\section{b) International treaties}

This is much clearer. For the first time in 1974 - shortly after France (the last then member state to do so) ratified the Convention and recognised the right of individual petition to the European Court of Human Rights - the Court first took notice of international treaties for the protection of human rights on which the member states have collaborated or of which they are signatories as a source of fundamental rights recognised by Community law ${ }^{36}$ - the most important being, of course, the European Convention, to which all member states but France had been party prior to ratification of the Community/Union Treaties. The Convention is now formally recognised (and codified) as such in article 6(2) of the Treaty on European Union, which draws it unilaterally into the Union legal system:

The Union shall respect fundamental rights, as guaranteed by the European Convention for the Protection of Human Rights and Fundamental Freedoms [...] and as they result from the constitutional traditions common to the Member States, as general principles of Community law.

The standard formula adopted by the Court became:

[I]t is settled case law that fundamental rights form an integral part of the general principles of Community law whose observance is ensured by the Community judicature. For that purpose, the Court of Justice and the Court of First Instance draw inspiration from the constitutional traditions common to the Member States and from the guidelines supplied by international treaties for the protection of human rights on which the Member States have collaborated and to which they are signatories. The Convention has special significance in this respect. ${ }^{37}$

4(2)) which does not however alter the validity or effect of the law (s 4(6)). To do more would require Parliament to disable its own omnicompetence, which in British constitutional law it cannot do. For a (high profile) example of a declaration of incompatibility see $A v$ Secretary of State for the Home Department [2005] UKHL 71, [2006] 2 AC 221.

36 Case 4/73 Nold $v$ Commission [1974] ECR 491.

37 Case T-112/98 Mannesmannröhren-Werke v Commission [2001] ECR II-729 para 60. For essentially identical constructions, see Opinion 2/94 Re Accession to the ECHR [1996] ECR I-1759 para 33; Case C-299/95 Kremzow v Austria [1997] ECR I-2629 para 14; Case 
And it is a principle which extends beyond Community law to apply also to the conduct of the Union:

[I]n accordance with Article 6(2) EU, the Union must respect fundamental rights, as guaranteed by the European Convention for the Protection of Human Rights and Fundamental Freedoms. [...]

The Framework Decision must thus be interpreted in such a way that fundamental rights, including in particular the right to a fair trial as set out in Article 6 of the Convention and interpreted by the European Court of Human Rights, are respected. ${ }^{38}$

However, the Court was long careful to 'draw inspiration' from the Convention, and not apply it directly. Hence, it would say, for example:

Article 6(1) of the EHRC [sic] provides that in the determination of his civil rights and obligations or of any criminal charge against him, everyone is entitled to a fair and public hearing within a reasonable time by an independent and impartial tribunal established by law.

The general principle of Community law that everyone is entitled to a fair legal process, which is inspired by those fundamental rights $[\ldots] .{ }^{39}$

Alternatively,

Respect for that presumption [of innocence] is required of the Commission [...] by virtue of the fact that it is a fundamental right guaranteed by the ECHR and therefore a general principle of Community law pursuant to Article 6(2) EU and the settled case-law of the Community Courts. ${ }^{40}$

This is because the Community is not party to the Convention, and so, notwithstanding reference to respect of fundamental rights 'as guaranteed by the European Convention' in article 6 of the TEU, it is not 'as such' part of Community (or Union) law; ${ }^{41}$ and under the present Treaty it has no constitutional power to accede to it. ${ }^{42}$ However the Court edged gradually ever closer to an embrace with the Convention - for example, Advocate-General Jacobs in 1996:

C-7/98 Krombach v Bamberski [2000] ECR I-1935 para 25; Case C-94/00 Roquette Frères v Directeur Général de la Concurrence [2002] ECR I-9011 para 23.

38 Case C-105/03 Criminal proceedings against Pupino [2005] ECR I-5285 paras 58-59.

39 Case C-185/95P Baustahlgewebe $v$ Commission [1998] ECR I-8417 paras 20-21.

40 Cases T-22 \& 23/02 Sumitomo Chemical Co $v$ Commission [2005] ECR II-4065 para 69.

41 Case T-112/98 Mannesmannröhren-Werke $v$ Commission [2001] ECR II-729 para 59.

42 Opinion 2/94 Re Accession to the ECHR [1996] ECR I-1759. 
Although the Community itself is not a party to the Convention [...] and although the Convention may not be formally binding upon the Community, nevertheless for practical purposes the Convention can be regarded as part of Community law and can be invoked as such both in this court and in national courts. ${ }^{43}$

And in 2004 the Court, for the first time, applied the Convention directly: citing case law of the Court of Human Rights which found the refusal of English law to recognise gender reassignment to breach a transsexual's right to marry under article 12 of the Convention,,$^{44}$ it found it also to infringe a Community right to a spouse's pension rights, and so said:

Article $141 \mathrm{EC}$, in principle, precludes legislation, such as that at issue before the national court, which, in breach of the European Convention for the Protection of Human Rights and Fundamental Freedoms, prevents [the enjoyment of a Community law right]. ${ }^{45}$

More recently, in a case involving Union (not Community) legislation, it said:

[I]n accordance with Article 6(2) EU, the Union must respect fundamental rights, as guaranteed by the European Convention [...].

The Framework Decision must thus be interpreted in such a way that fundamental rights, including in particular the right to a fair trial as set out in Article 6 of the Convention and interpreted by the European Court of Human Rights, are respected. ${ }^{46}$

And back to the Community sphere:

The obligations [imposed upon lawyers] of information and of cooperation with the authorities responsible for combating money laundering, laid down in [a directive], do not infringe the right to a fair trial as guaranteed by Article 6 of the Convention for the Protection of Human Rights and Fundamental Freedoms and Article 6(2) EU. ${ }^{47}$

\footnotetext{
43 Case C-85/94 Bosphorus Hava Yollari Turizm ve Ticaret $v$ Minister for Transport, Ireland [1996] ECR I-3953, per opinion of AG Jacobs para 53.

44 Goodwin v United Kingdom (App no 28957/95) (2002) 35 EHRR 447; I v United Kingdom (App no 25680/94) (2003) 36 EHRR 967.

45 Case C-117/01 K.B. v National Health Service Pensions Agency [2004] ECR I-541, in the dispositif.

46 Case C-105/03 Criminal proceedings against Pupino [2005] ECR I-5285 paras 58-59.

47 Case C-305/05 Ordre des barreaux francophones et germanophone $v$ Conseil des Ministres (ECJ 26 June 2007), in the dispositif.
} 
The Court thus seems now to have acquired the taste for direct application of the Convention. It may, or may not, be relevant that four of the ten judges appointed upon the 2004 accessions had served previously as judges of the Court of Human Rights. ${ }^{48}$ Whether formal accession to the Convention would lead to significant change in the application of these principles in Community law is a matter of spirited debate. But it is incontestable that because Community conduct is not directly subject to the jurisdiction of the European Court of Human Rights, and even if the Court of Justice 'pays the greatest heed to the case-law of the European Court of Human Rights', ${ }^{49}$ there will inevitably be fissures between Strasbourg case law (on the Convention) and Luxembourg case law (on Community law inspired by it)..$^{50}$ Even if applying the Convention directly as it is now increasingly wont to do, inconsistencies are very likely to arise. It is not necessarily the case that Luxembourg will get it wrong, that it will in some way be 'soft' on Convention rights: the Court of Justice has allowed and will allow human rights to trump even fundamental economic rights of the Treaty provided there is objective justification and the hindrance is not disproportionate. ${ }^{51}$ But this illustrates the cultural difference between Luxembourg and Strasbourg: the former will identify a Treaty imperative and then consider whether derogation is justified by application of quite strict exculpatory rules; the latter will identify a Convention right and require its protection, subject perhaps to a public authority's margin of appreciation. They come at it from different directions. Therefore Luxembourg may get it wrong. This is, after all, why the Treaty does not trust high national courts to interpret Community law on their own and requires that they refer any such matter to the Court of Justice, ${ }^{52}$ unless it has already been decided by the Court or its correct interpretation is acte clair. ${ }^{53}$ Ought Strasbourg to have a higher degree

\footnotetext{
48 That is, Judges Küris, Levits, Lõhmus and Makarczyk.

49 Case C-466/00 Kaba v Secretary of State for the Home Department [2003] ECR I-2219, per opinion of AG Ruiz-Jarabo Colomer para 89.

50 See, to select one example, Case C-94/00 Roquette Frères v Directeur Général de la Concurrence [2002] ECR I-9011, in which the Court of Justice was required to re-assess its previous Hoechst (Cases 46/87 \& 227/88 Hoechst $v$ Commission [1989] ECR 2859) case law on the inviolability of premises in the light of intervening judgments of the Court of Human Rights.

51 See eg Case C-112/00 Eugen Schmidberger, Internationale Transporte und Planzüge $v$ Austria [2003] ECR I-5659 (right of assembly v free movement of goods); Case C-36/02 Omega Spielhallen- und Automatenaufstellungs $v$ Oberbürgermeisterin der Bundesstadt Bonn [2004] ECR I-9609 (human dignity v freedom to provide services). See also Case C341/05 Laval un Partneri $v$ Svenska Byggnadsarbetareförbundet (pending) (collective industrial action v freedom to provide services); Case C-438/05 International Transport Workers' Federation $v$ Viking Line (pending) (collective industrial action $\mathrm{v}$ right of establishment).

52 Art 234 EC Treaty para 3.

53 Cases 28-30/62 da Costa en Schaake v Nederlandse Belastingsadministratie [1963] ECR 31; Case 283/81 CILFIT v Ministero della Sanità [1982] ECR 3415; Case C-495/03 Intermodal Transports $v$ Staatssecretaris van Financiën [2005] ECR I-8151.
} 
of faith in Luxembourg? - for unlike the event of a national court falling short on Convention standards, there is no right of petition from a Luxembourg judgment. The Treaty establishing a Constitution for Europe required the Union to seek accession to the Convention, ${ }^{54}$ so removing the present treaty bar, and that provision is intended by the European Council to survive into the redrafted Reform Treaty; ${ }^{55}$ but it will also require, first, amendment to the Convention itself, for it is ancillary to the Council of Europe, which at present is open for accession to states only; and second, serious consideration of the collaboration, and hierarchy, between Strasbourg and Luxembourg.

\section{c) The Charter of Fundamental Rights of the European Union}

This is the clearest, least nebulous, purpose built codification of fundamental rights in Community law. ${ }^{56}$ It is the fruit of long debate within the Union on the nature of fundamental rights: the rights which ought to be embraced, whether they ought to be legally binding, and if so how, whether they ought to be incorporated into Treaty texts or simply 'declared', and if so by whom, whether they ought to bind (if anyone) the Community/Union institutions only, the member states acting within Community/Union spheres, the member states in areas unrelated to Community law, and so on. In the event, the Charter is a fairly comprehensive codification of essentially personal rights 'recognised' by the Union ${ }^{57}$ - 54 articles divided into seven chapters, addressing dignity, freedoms, equality, solidarity, citizens' rights, justice, and a final chapter on general provisions. It is unique amongst international instruments in the breadth of its subject matter.

But the Charter does not form part of the Treaty. It was adopted at the Nice Summit in December 2000 by the Parliament, the Council and the Commission by 'solemn proclamation', so, however 'solemn', it is a product not of the constituent authorities of the Treaties (the Herren der Verträge) but of the three political institutions. This they had done once before, ${ }^{58}$ admittedly far less ambitiously, and to limited effect. Further, at

\footnotetext{
54 Treaty establishing a Constitution for Europe art I-9(2).

55 Draft Treaty on European Union (as amended by the Draft Treaty amending the Treaty on European Union and the Treaty establishing the European Community (the 'Reform Treaty'); hereinafter Draft TEU) art 6(2).

56 For the present text of the Charter, see [2000] OJ C364/1.

57 Preamble, $7^{\text {th }}$ indent.

58 'Joint Declaration on fundamental rights of the European Parliament, the Council and the Commission of 5 April 1977' [1977] OJ C103/1. See also the Community Charter of the Fundamental Social Rights of Workers (text reproduced in Social Europe 1/90), a declaration agreed by eleven of the then twelve heads of state or government at the Strasbourg Summit in 1989, elements of which surface in the Charter.
} 
Nice the member states least enthusiastic of fundamental rights initiatives secured a victory of sorts. Article 51 of the Charter (within the chapter on general provisions, defining the 'Scope' of the Charter) provides:

1. The provisions of this Charter are addressed to the institutions and bodies of the Union with due regard for the principle of subsidiarity and to the Member States only when they are implementing Union law. They shall therefore respect the rights, observe the principles and promote the application thereof in accordance with their respective powers.

2. This Charter does not establish any new power or task for the Community or the Union, or modify powers and tasks defined by the Treaties.

There is real concern that the application of the Charter to the conduct of the member states 'only when they are implementing [uniquement lorsqu'ils mettent en ouvre] Union law' is a backward step, excluding judicial control over national measures which derogate from Community rules. There is as yet no judicial authority on this.

Even though outside the Treaties, the Charter yields greater precision to those rights already recognised as forming part of Community law. Within two months of its adoption it was being cited, with approbation, by an Advocate-General as an aid to interpretation of a social policy directive. ${ }^{59}$ According to the Court of First Instance, '[a]lthough this document does not have legally binding force, it does show the importance of the rights its sets out in the Community legal order. ${ }^{60}$ And the Court of Justice finally took proper notice of it in 2006 in the Family Reunification case,${ }^{61}$ although in a compromise step it said the Charter had relevance insofar as it reflected the constitutional traditions of or international obligations common to the member states. It is also incorporated from time to time expressly into Community legislation: Regulation 1/2003, for ex-

\footnotetext{
59 Case C-173/99 $R v$ Secretary of State for Trade and Industry, ex parte Broadcasting, Entertainment, Cinematographic and Theatre Union [2001] ECR I-4881, per opinion of AG Tizzano paras 26-28. For subsequent (approbatory) reference to the Charter by AdvocatesGeneral, see Cases C-20 \& 64/00 Booker Aquaculture $v$ The Scottish Ministers [2003] ECR I-741 1 (AG Mischo); Case C-181/03P Nardone v Commission [2005] ECR I-199 (AG Poiares Maduro); Cases C-387 etc/02 Berlusconi v Parliament [2005] ECR I-3565 (AG Kokott); Case C-540/03 Parliament $v$ Council [2006] ECR I-5769 (AG Kokott); Case C-105/04P Nederlandse Federatieve Vereniging voor de Groothandel op Elektroteknisch Gebeid $v$ Commission [2006] ECR I-8725 (AG Kokott); Case C-354/04P Gestoras Pro Amnistía v Council (ECJ 27 February 2007) (AG Mengozzi); Case C-328/05P SGL Carbon $v$ Commission (ECJ 10 May 2007) (AG Mazák); Case C-305/05 Ordre des barreaux francophones et germanophone $v$ Conseil des Ministres (ECJ 26 June 2007) (AG Poiares Maduro).

60 Cases T-377 etc/00 Philip Morris International $v$ Commission [2003] ECR II-1 para 122.

61 Case C-540/03 Parliament $v$ Council [2006] ECR I-5769.
} 
ample, the cornerstone of the (now) decentralised enforcement of Community competition rules, provides that

[t]his Regulation respects the fundamental rights and observes the principles recognised in particular by the Charter of Fundamental Rights of the European Union. Accordingly, this Regulation should be interpreted and applied with respect to those rights and principles. ${ }^{62}$

This fixes the Charter to the given field of Community law and requires its application thereto, at least insofar as a preambular reference has relevance to the application of a regulation; if nothing else it ought to concentrate the minds of the authorities wielding it. And the more often it is flagged up, the more familiar it becomes.

However significant a step the Charter may be, it may grow to become more significant still. Certainly '[t]he Commission considers that the Charter, by reason of its content, its tight drafting and its high political and symbolic value, ought properly to be incorporated in the Treaties sooner or later. ${ }^{63}$ It was in the event (intended to be) incorporated into the Treaties sooner, by the Treaty establishing a Constitution for Europe, comprising Part II (of four Parts). There are minor, 'though significant, differences between the text of the Charter and the text adopted in the Constitution, but essentially they are the same thing. So, had the Treaty been ratified, the Charter would have acquired 'constitutional' status, and its place within the Community/Union hierarchy of norms would be much clearer. The Constitutional Treaty now abandoned but much of it cannibalised in the Reform Treaty, the solution now proposed is, rather than Treaty incorporation, that the Union 'recognises the rights, freedoms and principles set out in the Charter [...] which shall have the same legal value as the Treaties' ${ }^{4}$ (emphasis added) and will have 'legally binding force'. ${ }^{65}$ This is a half-way house, designed primarily not to frighten the (British) horses; but it seems likely the Charter (in its Constitutional Treaty version) ${ }^{66}$ will, albeit through the back door, finally

62 Regulation (EC) 1/2003 of 16 December 2002 on the implementation of the rules on competition laid down in Articles 81 and 82 of the Treaty [2003] OJ L1/1, preamble, recital 37.

63 EC Commission, 'Communique on the Legal Nature of the Charter of Fundamental Rights of the European Union' COM (2000) 644 final, 11 October 2000 para 11.

64 Art 6(1) Draft TEU.

65 Draft Declaration (No 31) concerning the Charter of Fundamental Rights, para 1.

66 The European Council intends the Parliament, Council and Commission again solemnly to proclaim the Charter on the day the Reform Treaty is signed in the version agreed at the 2004 IGC; draft Declaration (No 11) on the Proclamation of the Charter of Fundamental Rights by the European Parliament, the Council and the Commission. 
gain Treaty stature and force. Thus ramped up, the Court of Justice will thereafter be charged with applying the Charter to the conduct of the institutions and the member states 'only when they are implementing Union law ${ }^{67}$ whilst continuing to respect 'fundamental rights, as guaranteed by the European Convention'68 across the spectrum of Union activity. The Charter may therefore be of narrower application than the Convention (depending upon what 'only when they are implementing Union law' means), whilst even if it 'confirms the fundamental rights guaranteed by the European Convention' 69 it may in substance be wider, the Convention forming a subset ratione materiae of the more broadly framed Charter. Therefore a robust application of the Charter will necessarily be on all fours with the Convention. A safeguard to this purpose may be found in the Charter itself:

In so far as this Charter contains rights which correspond to rights guaranteed by the Convention for the Protection of Human Rights and Fundamental Freedoms, the meaning and scope of those rights shall be the same as those laid down by the said Convention. This provision shall not prevent Union law providing more extensive protection. ${ }^{70}$

The question is whether the Court of Justice will apply it robustly, or as robustly as Strasbourg would the Convention 'corresponding rights' which forms its core. Synergy between Charter and Convention may be achieved by other means, for example by the EU Network of Independent Experts on Fundamental Rights created in 2002 by the Commission upon a recommendation of the Parliament to report on human rights situations within the Union: it uses the Charter as its 'reference instrument', but it is 'indexed' to international and European human rights law. ${ }^{71}$ But whilst it may come to achieve much, the Network marks yet further decentralisation of authority in the field.

\section{Sanctions for non-compliance with human rights in the Union}

Note must be taken of the sanctions now available where a member state fails to comply with its human rights obligations within the Union. Article 6 of the TEU, which applies to all Union (including Community) activity, provides:

67 Charter of Fundamental Rights art 51.

68 Art 6(3) Draft TEU.

69 Draft Declaration (No 31) (n 65) para 1.

70 Charter of Fundamental Rights art 52(3).

${ }^{71}$ See the Network's (first annual) 'Report on the Situation of Fundamental Rights in the European Union and its Member States in 2002' (31 March 2003) 11-24. 
1. The Union is founded on the principles of liberty, democracy, respect for human rights and fundamental freedoms, and the rule of law, principles which are common to the Member States.

2. The Union shall respect fundamental rights, as guaranteed by the European Convention [...].

In 1996 the Court of Justice said that the institutions had no power to adopt general rules on human rights. ${ }^{72}$ This was remedied, at least in the view of the Commission, by amendments made to article 7 of the TEU by the Treaty of Nice, ${ }^{73}$ article 7 now providing the authority and mechanism for the adoption of sanctions against a member state found 'serious[ly] and persistent[ly]' to breach the principles set out in article 6(1). ${ }^{74}$ The power of sanction applies in Union matters and is expressly carried over into the Community sphere ${ }^{75}$ but, according to the Commission, its scope is not confined to them. ${ }^{76}$ If this is so, the Union may vent its displeasure against a member state even where it is acting wholly within the national domain, or acting in some other way which has no Community/Union/Charter element. The closest practical instance of this is l'affaire autrichienne in 2000, in which 14 of the then 15 member states sought to boycott Austria in a number of Community, Union and non-Union spheres in order to protest at the (minor) participation in federal government of the Freiheits Partei Österreich. ${ }^{77}$ But there was no

72 Opinion 2/94 Re Accession to the ECHR [1996] ECR I-1759.

73 See EC Commission, 'Communication to the Council and the European Parliament on Article 7 of the Treaty on European Union: Respect for and promotion of the values on which the Union is based' (Communication) COM (2003) 606, 15 October 2003, 3: 'the amended Article 7 confers new powers on the Commission in its monitoring of fundamental rights in the Union'.

74 Action taken under art 7 now takes two forms: first (a Nice innovation), upon a 'reasoned proposal' from the Parliament, the Commission or one third of the member states, and with the assent of the Parliament (acting by a two-thirds majority vote representing a majority of MEPs), the Council may by a majority of four-fifths of its members determine that there is a 'clear risk of a serious breach' of art 6(1) and address appropriate recommendations (but no more) to the errant member state (art 7(1)). Second, upon a proposal from the Commission or one third of the member states, and with the (same weighted) assent of the Parliament, the Council, meeting in the composition of heads of state or government, may by unanimity (excepting the vote of the errant member state) determine the existence of a 'serious and persistent breach' of art 6(1), after which the Council may by qualified majority suspend 'certain of the member state's Treaty rights, including Council voting rights (art 7(2)-(5)).

75 Art 309 EC Treaty.

76 EC Commission, 'Communication to the Council [...] on Article 7' (n 73) 5.

77 In the 1999 election the FPÖ won 27 percent of the popular vote, making it the second largest party in the Nationalrat, and agreed to form a collation government with the Österreichische Volkspartei (ÖVP). This led to weekly demonstrations (the Donnerstagsdemonstrationen) in Vienna and the boycott measures adopted by the other member states. The 'Statement of the XIV' said this state of affairs would last 'as long as necessary', but crumbled after 7 months. It raises the interesting question of whether the boycott itself was 
recourse, and the events cannot be taken as action adopted pursuant, to article 7; in fact a subsequent report exonerated Austria of human rights abuses of any kind.$^{78}$ Nor has action been taken under article 7 following the 2003 invasion of Iraq against the member states party to it, notwithstanding war of aggression being identified by the European Parliament as 'a clear risk of a breach [...] or an actual breach' of article $6 .^{79}$ In the view of one commentator, '[i]f an external war and occupation of a sovereign state did not create a prima facie situation for scrutiny it is hard to imagine any condition other than the most extreme form of tyrannical behaviour forcing a response. ${ }^{80}$

Well, torture might constitute such a condition. Yet allegations of 'extraordinary rendition flights' in and through a number of member states - refoulement prohibited (probably with the force of jus cogens) in international law, ${ }^{81}$ under the Convention ${ }^{82}$ and under the Charter, ${ }^{83}$ and prohibited absolutely ${ }^{84}$ - and of related torture in some member states, now confirmed convincingly in the two 'Marty Reports' under the auspices of the Council of Europe,$^{85}$ have drawn no fire. This is of course the major weakness of article 7 , namely its fierce procedural hurdles: if member states work together to a common purpose, or at least in mutual contempt of fundamental rights, sufficient support in the Council for effective action is unlikely to be mustered. It was hoped by some that

consistent with the art 6(1) commitment to (Austrian) democracy, and if and how Austria (or an Austrian) might have challenged it on that ground. For discussion of the affair, see G de Búrca, 'Beyond the Charter: How Enlargement has Enlarged the Human Rights Policy of the European Union' (2004) 27 Fordham International Law Journal 679.

78 M Ahtisaari, J Frowein and M Oreja, 'Report on the Austrian Government's Commitment to the Common European Values, in particular concerning the rights of Minorities, Refugees and Immigrants, and the Evolution of the Political Nature of the FPÖ (The Wise Men Report)' (2001) 40 International Legal Materials 102.

79 European Parliament, Committee on Constitutional Affairs, 'Report on the Commission communication on Article 7 of the Treaty on European Union: Respect for and promotion of the values on which the Union is based' (1 April 2004) A5-0227/2004, 11.

80 A. Williams, 'The Indifferent Gesture: Article 7 TEU, the Fundamental Rights Agency and the UK's Invasion of Iraq', (2006) 31 EL Rev 3, 11-12.

81 UN Convention against Torture and Other Cruel, Inhuman or Degrading Treatment or Punishment 1984 (adopted 10 December 1984, entered into force 26 June 1987) 1465 UNTS 85 art 3.

82 Art 3 ECHR.

83 Charter of Fundamental Rights art 19(2).

84 Chahal $v$ United Kingdom (App no 22414/93) (1997) 23 EHRR 413; also Ramzy v Netherlands (App no 25424/05) (pending).

85 Council of Europe, Parliamentary Assembly, Committee on Legal Affairs and Human Rights, 'Alleged secret detentions and unlawful inter-state transfers of detainees involving Council of Europe member states' (7 June 2006) AS/Jur (2006) 16 and 'Secret detentions and illegal transfer of detainees involving Council of Europe member states: second report' (7 June 2007) AS/Jur (2007) 36. 
the European Agency for Fundamental Rights (EUAFR), which took up its duties in March 2007, ${ }^{86}$ would be afforded some formal role in the application of article 7 , but they were to be denied. Its scope is further restricted to the application of Community law, ${ }^{87}$ which leaves it powerless to pursue (alleged) Convention breaches by the Union under Titles V or VI and by member states in wholly national spheres. So the Agency may 'assist' in ${ }^{88}$ and 'deal with', ${ }^{89}$ for example, discrimination in employment law for its inconsistency with fundamental human rights, but not so invasion and torture.

The protection of human rights in Europe therefore still springs less from political institutions than from the courts - and increasingly, a double act between the Court of Human Rights and the Court of Justice. There is a slow growth of recognition - and slower still, respect - between the two courts. They now cite each other with increasing regularity and, more recently, approbation. It is natural for the Court of Justice to do so, the Treaty now citing the Convention and the Court of Human Rights an obvious authority in its interpretation, although the Court (as opposed to the Advocates-General) did so expressly for the first time only in $1996 .{ }^{90}$ The Court of Human Rights cited Luxembourg earlier ${ }^{91}$ but less frequently, and each now sometimes returns the courtesies. ${ }^{92}$ This may be likened to an (amicable) game of chess between Strasbourg and Luxembourg; put otherwise, 'a symbiotic interaction of fragile complexity, continuously working out a solution to the sometimes awkward co-existence of the EU and the ECHR'. ${ }^{93}$ In order best to understand whither this danse judicaire has now led us, and the (precarious) balance now struck, it will be necessary to consider four recent judgments, two from Strasbourg and two from Luxembourg.

\footnotetext{
86 Council Regulation (EC) 168/2007 of 15 February 2007 establishing a European Union Agency for Fundamental Rights [2007] OJ L53/1. The Agency replaced, and succeeded to the responsibilities of, the European Monitoring Centre on Racism and Xenophobia; like the Centre before it, it has its seat in Vienna.

87 Ibid art 3.

88 Ibid art 2.

89 Ibid art 3(3).

90 Case C-13/94 P v S and Cornwall County Council [1996] ECR I-2143.

91 For the first time in Marckx $v$ Belgium (App no 6833/74) (1979) 2 EHRR 330, and not again until the 1990s.

92 In Case C-13/94 P v S (n 90), Luxembourg cited Strasbourg in Rees $v$ United Kingdom (App no 9532/81) (1986) 9 EHRR 56; Strasbourg cited P v S in turn in Goodwin $v$ United Kingdom (App no 28975/95) (2002) 35 EHRR 447, and Luxembourg then cited Goodwin in Case C-117/01 K.B. v National Health Service Pensions Agency [2004] ECR I-541. On the growing mutual support between the two courts, see S Douglas-Scott, 'A Tale of Two Courts: Luxembourg, Strasbourg and the Growing European Human Rights Acquis' (2006) 43 CML Rev 629, 640-652.

93 Douglas-Scott (n 92) 631.
} 


\section{Matthews}

Miss Matthews was a citizen and resident of Gibraltar, part of Her Majesty's dominions for which the United Kingdom is responsible in international (and Community) law, but constitutionally distinct from the UK. In accordance with article 227(4) of the EC Treaty, it became part of the Community with UK accession in 1973, but it is not part of the customs territory, and in many ways is treated as a third country. Citizens of Gibraltar are citizens of the Union. ${ }^{94}$ Accordingly, in 1994 Miss Matthews petitioned the Chief Electoral Office of Gibraltar to be registered as a voter for the elections to be held that year to the European Parliament. He replied that both the 'Act' Concerning the Election of the Representatives of the Assembly by Direct Universal Suffrage ${ }^{95}$ and the UK legislation giving effect to it ${ }^{96}$ limited the franchise to the territory of the United Kingdom. She therefore had no vote.

The Convention extends to Gibraltar by virtue of a 1953 declaration made by the UK government; Protocol 1 was made effective there by virtue of a 1988 declaration. Miss Matthews therefore claimed a violation of protocol 1, article 3, taken alone or in conjunction with article 14 of the Convention. Article 3 of protocol 1 provides: 'The High Contracting Parties undertake to hold free elections at reasonable intervals by secret ballot, under conditions which will ensure the free expression of the opinion of the people in the choice of the legislature.' Article 14 of the Convention prohibits discrimination in the application of the Convention, but in the event the Court found it unnecessary to consider.

The issue here for present purposes was that the measure which it was claimed infringed the Convention was a measure adopted under the three Community treaties. More accurately, it was a peculiar instrument envisaged in, and called for by, the Treaty ${ }^{97}$ but was not an act of the institutions acting under Treaty authority (which is normally the case), rather it was adopted in the form of a decision of the Council composed of representatives of the member states ('the member states au sein $d u$ Conseil') and acting unanimously, and made effective by its subsequent ratification by all member states. Once in force it acquired Treaty status. Because it was a measure adopted by the Communities it could not be challenged before the Court of Human Rights because they are not contracting parties to the Convention. And nor could it be challenged in Luxembourg, for it was not a normal Community act, rather it had treaty

94 British Nationality Act 1981, ss 15ff, 50(1), Sch 6; Declaration by the United Kingdom replacing the [1972] Declaration on the Definition of the term 'Nationals' [1983] OJ C23/1.

95 [1976] OJ L278/1.

96 The European Parliamentary Elections Act 1978.

97 Art 138(3) EEC Treaty. 
status and was beyond the reach of the Court of Justice. The issue was therefore whether the United Kingdom could be held accountable for the (alleged) breach of the Convention.

The Commission of Human Rights (the case having been raised before the Commission became redundant in 1998) found the application admissible but by 11 votes to 6 found that there had been no violation of article 3 of protocol 1 . The Court (by 15 votes to 2) disagreed. ${ }^{98}$ Article 1 of the Convention requires the High Contracting Parties to 'secure to everyone within their jurisdiction the rights and freedoms defined in [the] Convention'. It makes no distinction as to the type of rule or measure concerned, and does not exclude any part of the member States' 'jurisdiction' from scrutiny. But can the UK be responsible for a rule adopted by Community authorities, from which there was no derogation and which could be changed only with the consent of all member states?

The Community is not subject to the jurisdiction of the Court of $\mathrm{Hu}-$ man Rights. But whilst it does not object to transfer of state competences to an international organisation, the Convention requires that its rights continue to be 'secured'. Member States' responsibility therefore continues and survives even after such a transfer.

Here then is the answer, the Strasbourg view of the continuing place of the Convention in Community (and Union) law, and implicitly article 30 of the Vienna Convention and article 307 of the EC Treaty. It is a half-way house, put with greater clarity in another, contemporaneous judgment:

[W]here States establish international organisations in order to pursue or strengthen their cooperation in certain fields of activities, and where they attribute to these organisations certain competences and accord them immunities, there may be implications as to the protection of fundamental rights. It would be incompatible with the purpose and object of the Convention, however, if the Contracting States were thereby absolved from their responsibility under the Convention in relation to the field of activity covered by such attribution. ${ }^{99}$

Convention rights continue to subsist even between and amongst the Community member states and their citizens. Yet the creation of the Community and its forays into fundamental rights are compatible with

\footnotetext{
98 Matthews $v$ United Kingdom (App no 24833/94) (1999) 28 EHRR 361.

99 Waite \& Kennedy $v$ Federal Republic of Germany (App no 26083/94) (1999) 30 EHRR 261 para 67. In fact the subsisting obligations of a contracting party to the Convention in the face of subsequent international obligations was indicated by the Commission of Human Rights as early as 1958: X v Federal Republic of Germany (App no 342/57) (4 September 1958, unreported).
} 
the Convention provided that Convention rights 'receive an equivalent protection' ${ }^{100}$ or continue to be 'secured'. ${ }^{101}$ This accords with the (subsequent) opinion of the EU network of independent experts on fundamental rights:

Where contracting parties fail to take human rights properly into account, or where a treaty leads to infringements of human rights whether or not such violations could be anticipated when the treaty was concluded, the parties concerned can be held responsible for such violations: the obligation to secure the enjoyment of human rights and fundamental freedoms continues to exist after the conclusion of a treaty with third parties. This is in conformity with the rule expressed in Article 30 of the Vienna Convention on the Law of Treaties [...]. ${ }^{102}$

It is also entirely in harmony with the legal thinking of the Bundesverfassungsgericht in its Solange I judgment. ${ }^{103}$

Here, the violation flows from a Community act, entered into by the United Kingdom. The United Kingdom, together with all other member states, is responsible ratione materiae under article 1 of the Convention and, in this case in particular, under article 3 of protocol 1, for the consequences of the Treaty. The Court therefore found for Miss Matthews, who recovered no damages (she had claimed none) but was awarded costs and, from the 2004 European elections, the right to vote. ${ }^{104}$

So Matthews tells us that Convention responsibilities and Convention jurisdiction remain alive for the member states even within the Community cocoon. The Community may succeed to the member states' obligations under the Convention, but if the Community fails to comply with them, the responsibility of the member state will reassert itself. The problem with Matthews is that the issue involved the application of a Community measure which was beyond the control of the Court of Justice. This

100 M \& Co. v Germany (App no 13258/87) (1990) 64 DR 138, 145.

101 Matthews (n 98) para 32.

102 'Opinion No 3-2006: The Human Rights Responsibilities of the EU Member States in the Context of the C.I.A. Activities in Europe (“Extraordinary Renditions”)' (25 May 2006) 10.

103 BVerfG, 29. Mai 1974, BVerfGE 37, 271.

104 The UK law adopted to comply with the judgment of the Court (the European Parliamentary (Representation) Act 2003) was challenged before the Court of Justice by Spain (Case C-145/04 Spain v United Kingdom [2006] ECR I-7917, one of the very rare cases of enforcement proceedings raised under art 227 by a member state) on the grounds that the peculiarity of UK electoral law which grants full voting rights to resident non-UK Commonwealth citizens, and so enfranchising for elections to the European Parliament (some one hundred) non-citizens of the Union resident in Gibraltar, infringed various provisions of the Treaty. The Court disagreed, finding Community law not to preclude a member state from enfranchising third country nationals 'who have close links to [it]' (para 78). 
does not happen often, most Community law is reviewable by the Court; this was not. The question is then whether Convention responsibility will survive where there is control (effective or otherwise) in Luxembourg.

\section{Jégo-Quéré and Unión de Pequeños Agricultores}

It was anticipated that the test would come in the context of article 6 of the Convention, which provides for and requires effective judicial protection of rights. In 2002 there was some excitement in Community circles when the Court of Justice began to play with the Treaty scheme for the judicial protection of the individual before it - in essence the question of whether individual access to the Court under article 230 of the EC Treaty for the judicial challenge of a Community measure, as first defined in the Plaumann judgment, ${ }^{105}$ afforded adequate protection for the rights of the individual. Advocate-General Jacobs thought not: he proposed that the Community system was inadequate; it was arbitrary; it was restrictive; it was discriminatory; it would in many cases require the individual to breach the law, and sometimes criminal law, in order to trigger judicial review of the law. This situation 'does not offer the individual an adequate means of judicial protection. Individuals clearly cannot be required to breach the law in order to gain access to justice. ${ }^{106}$ Therefore he said, the Community system was incompatible with the principle of effective judicial protection (implicitly as required by article 6 of the Convention), and proposed a significant re-evaluation of the case law under article 230 , so that

an individual should be regarded as individually concerned within the meaning of the fourth paragraph of Article 230 EC by a Community measure where, by reason of his particular circumstances, the measure has, or is liable to have, a substantial adverse effect on his interests. ${ }^{107}$

Before the Court of Justice delivered its judgment in the case the Court of First Instance intervened, and in an unrelated case agreed in principle with Mr Jacobs, although altered the substance of the test somewhat:

[A] natural or legal person is to be regarded as individually concerned by a Community measure of general application that concerns him directly if the measure in question affects his legal position, in a

105 Case 25/62 Plaumann v EEC Commission [1963] ECR 95.

106 Case C-50/00P Unión de Pequeños Agricultores v Council [2002] ECR I-6677, para 43 of his opinion.

107 Ibid para 103. 
manner which is both definite and immediate, by restricting his rights or by imposing obligations on him. The number and position of other persons who are likewise affected by the measure, or who may be so, are of no relevance in that regard. ${ }^{108}$

But, as is well known, the Court of Justice disagreed. The present system was quite adequate: the restricted access to the Court was a Treaty requirement, which could not be altered not by the Court but only by the member states, by treaty amendment. Until that should happen, it is the responsibility of the member states to ensure the existence of a system of legal remedies and procedures which adequately guarantee the right to effective judicial protection. ${ }^{109}$

The judgment in Unión de Pequeños Agricultores was one of the full Court (13 judges), and one clearly intended to constitute an arrêt de principe on the matter; it has been reconfirmed since. ${ }^{110}$ But it seems to a number of commentators that it is clearly wrong, and it is wrong because it was inconsistent with the Convention, in particular, of course, article 6. There was a feeling abroad that this may well be the Luxembourg view, but should Strasbourg ever be afforded the opportunity of pronouncing a view of the subject, however difficult that may be, the answer would be very different.

Strasbourg has now had the opportunity. And the answer is surprising.

\section{Bosphorus}

In 1992 Bosphorus Hava Yollari Turizm ve Ticaret AS, an airline charter company registered in Turkey with its seat in Istanbul, leased two aircraft from JAT, the national airline of the former Yugoslavia. The lease was for a period of 48 months from the dates of delivery of the two aircraft (22 April and 6 May 1992). The two aircraft were registered under the Turkish flag as foreseen by the lease.

In May 1993 one of the aircraft arrived in Dublin for maintenance work by an Irish company. A month earlier the UN Security Council had adopted a resolution ${ }^{111}$ requiring all $\mathrm{UN}$ states to impound, inter alia, all aircraft in their territories 'in which a majority or controlling interest is held by a person or undertaking in or operating' from the former Yugoslav Republic. The resolution was implemented in and for the Community by

108 Case T-177/01 Jégo-Quéré v Commission [2002] ECR II-2365 para 51.

109 Case C-50/00P Unión de Pequeños Agricultores (n 106).

110 Case C-167/02P Rothley v Parliament [2004] ECR I-3149; Case C-263/02P Commission v Jégo-Quéré [2004] ECR I-3425.

111 UNSC Res 820 (1993) UN Doc S/RES/ 820. 
a regulation which entered into force at the end of April. ${ }^{112}$ In June, in accordance with Irish law giving effect to the regulation, ${ }^{113}$ the Minister for Transport impounded the aircraft.

In November 1993 Bosphorus challenged the Minister's decision before the High Court. The High Court interpreted the Community regulation not to apply to the aircraft, and so the Minister had acted ultra vires. ${ }^{114}$ The Minister then re-imposed his decision, and at the same time appealed the judgment of the High Court to the Supreme Court. The Supreme Court decided it was bound to refer the question to the Court of Justice under article 234, and accordingly asked it, in effect, whether the aircraft was caught by, and the situation fell within, the regulation. The Advocate-General (Jacobs) addressed the question of fundamental rights at length, included amongst them a right to peaceful enjoyment of property, found a severe interference with Bosphorus's property rights, but that in the circumstances it was justified and not disproportionate. The Court agreed:

Article 8 of Regulation No 990/93 applies to an aircraft which is owned by an undertaking based in or operating from the Federal Republic of Yugoslavia (Serbia and Montenegro) even though the owner has leased it for four years to another undertaking, neither based in nor operating from that republic and in which no person or undertaking based in or operating from that republic has a majority or controlling interest. ${ }^{115}$

Four weeks later the Minister re-instated the impounding of the aircraft.

In 1997, following lapse of the lease and relaxation of the sanctions regime, the aircraft was returned to JAT (but which, to add insult to injury, was required to pay IR£389,609.95 to cover parking, maintenance, insurance and legal costs). In March Bosphorus lodged a complaint against Ireland with the European Commission of Human Rights, which was then transmitted to the Court. Essentially the complaint alleged a breach of article 1 of protocol 1, which provides:

\footnotetext{
112 Council Regulation (EEC) 990/93 of 26 April 1993 concerning trade between the European Economic Community and the Federal Republic of Yugoslavia (Serbia and Montenegro) [1993] OJ L102/14.

113 The European Communities (Prohibition of Trade with the Federal Republic of Yugoslavia (Serbia and Montenegro)) Regulations 1993 (SI 144 of 1993).

114 Bosphorus Hava Yollari Turizm ve Ticaret $v$ Minister for Transport [1994] 2 ILRM 551. 115 Case C-84/95 Bosphorus Hava Yollari Turizm ve Ticaret $v$ Minister for Transport, Ireland [1996] ECR I-3953 para 27.
} 
Every natural or legal person is entitled to the peaceful enjoyment of his possessions. No one shall be deprived of his possessions except in the public interest and subject to the conditions provided for by law and by the general principles of international law.

The preceding provisions shall not, however, in any way impair the right of a State to enforce such laws as it deems necessary to control the use of property in accordance with the general interest or to secure the payment of taxes or other contributions or penalties.

The case was assigned to the Grand Chamber of the Court. It gave its judgment in June 2005. ${ }^{116}$

What was remarkable in the judgment was the extensive consideration of Community law and practice by Strasbourg. The Luxembourg court makes increasing reference to Strasbourg case law (the AdvocatesGeneral extensively so), but here the shoe was on the other foot. The Court of Human Rights considered, and discussed at length:

- the development of the Luxembourg case law on fundamental rights;

- $\quad$ the Treaty provisions, particularly article 6 TEU, the Charter of Fundamental Rights and the provisions of the constitutional Treaty;

- the application of articles 10, 249 and 307 of the EC Treaty;

- the mechanisms of judicial protection in Community law, in particular articles 230, 232, 241, 288, direct effect, indirect effect, state liability and article 234 , and the extent of judicial protection afforded the individual, citing Unión de Pequeños Agricultores at considerable length. ${ }^{117}$

As to substance, the Irish government argued that the state was bound by the Luxembourg ruling. To do otherwise, even with a view to Convention compliance, would be contrary to its obligation of 'loyal cooperation' required by Community law. It argued essentially that Luxembourg and Strasbourg human rights protection were of an equivalent quality, and relied essentially upon $M \&$ Co., the 1990 decision of the Commission of Human Rights ${ }^{118}$ which found inadmissible a Convention challenge to a German measure enforcing a sanction (a pecuniary fine) adopted by the European Commission - as a national authority is obliged automatically to $\mathrm{do}^{119}$ - in the sphere of competition law because that would usurp the proper jurisdiction of the Community Court; the avail-

116 Bosphorus Hava Yollari Turizm ve Ticaret v Ireland (App no 45036/98) (2006) 42 EHRR 1.

117 Ibid para 85.

118 M \& Co. v Germany (n 100).

119 Art 256 EC Treaty. 
ability of a Luxembourg remedy, said the Irish government, distinguished this case from Matthews.

Bosphorus distinguished $M \& C o$. as an act of an international organisation over the elaboration of which the member state had no influence and in the execution of which the state had no discretion. Since it was not challenging the provisions of Regulation 990/93 or the sanctions regime per se, any 'equivalent protection' principle of the $M \& C o$. was not relevant. On the contrary, Ireland had been intimately involved in the adoption and application of the regulation and had, at all material times, a real and reviewable discretion as to the means by which the result required by it could be achieved. More generally, while the Convention did not exclude the transfer of competences to international organisations, the member state had to continue to secure Convention rights, otherwise it could escape its Convention responsibility once its courts referred a question and implemented a Luxembourg ruling. This would create an unacceptable lacuna of human rights protection in Europe. And in any event, Community law did not offer 'equivalent protection', and the procedure of article 234 of the EC Treaty was inadequate to ensure the level of protection required by article 6 of the Convention.

The EC Commission, as intervener, argued that whilst a State retained some Convention responsibility after it had ceded powers to an international organisation, that responsibility was fulfilled once there was proper provision in that organisation's structure for effective protection of fundamental rights at a level at least 'equivalent' to that of the Convention. It therefore supported the approach adopted in $M \& C o$. Ireland had no discretion here.

The Court found after extensive consideration, that what was at issue was not the result of an exercise of discretion by the Irish authorities, either under Community or Irish law, but rather amounted to compliance by the Irish State with its legal obligations flowing from EC law and, in particular, article 8 of Regulation 990/93. Then:

[T]he Court has recognised that absolving Contracting States completely from their Convention responsibility in the areas covered by such a transfer would be incompatible with the purpose and object of the Convention: the guarantees of the Convention could be limited or excluded at will thereby depriving it of its peremptory character and undermining the practical and effective nature of its safeguards. The State is considered to retain Convention liability in respect of treaty commitments subsequent to the entry into force of the Convention.

In the Court's view, State action taken in compliance with such legal obligations is justified as long as the relevant organisation is 
considered to protect fundamental rights, as regards both the substantive guarantees offered and the mechanisms controlling their observance, in a manner which can be considered at least equivalent to that for which the Convention provides. By 'equivalent' the Court means 'comparable': any requirement that the organisation's protection be 'identical' could run counter to the interest of international co-operation pursued. However, any such finding of equivalence could not be final and would be susceptible to review in the light of any relevant change in fundamental rights' protection.

If such equivalent protection is considered to be provided by the organisation, the presumption will be that a State has not departed from the requirements of the Convention when it does no more than implement legal obligations flowing from its membership of the organisation. However, any such presumption can be rebutted if, in the circumstances of a particular case, it is considered that the protection of Convention rights was manifestly deficient. In such cases, the interest of international cooperation would be outweighed by the Convention's role as a 'constitutional instrument of European public order' in the field of human rights [...].

Since the impugned act constituted solely compliance by Ireland with its legal obligations flowing from membership of the EC, the Court will now examine whether a presumption arises that Ireland complied with its Convention requirements in fulfilling such obligations and whether any such presumption has been rebutted in the circumstances of the present case. ${ }^{120}$

As to whether or not the presumption could or should be rebutted here, the Court examined the development of fundamental rights in Community law, and observed that although individual access to the Court in Luxembourg was limited, the availability of remedies before a national court 'greatly enlarged the role of the domestic courts in the enforcement of Community law and its fundamental rights' guarantees. ${ }^{121}$ Then,

'[i]n [the present] circumstances, the Court finds that the protection of fundamental rights by EC law can be considered to be, and to have been at the relevant time, 'equivalent' to that of the Convention system. Consequently, the presumption arises that Ireland did not depart from the requirements of the Convention when it implemented legal obligations flowing from its membership of the EC. ${ }^{122}$

\footnotetext{
120 Bosphorus (n 116) paras 154-158

121 Ibid para 164.

122 Ibid para 165.
} 
Finally, it went on the find that there was no reason by which the presumption could be rebutted in the case, found 'no dysfunction of the mechanisms of control of the observance of Convention rights', ${ }^{123}$ and therefore found no violation of the Convention.

\section{Where We Are Now}

The judgment in Bosphorus was a unanimous judgment, all 17 judges agreeing, of the Grand Chamber, and so a serious and authoritative contribution to the debate. Where does it lead us? First, it illustrates and reinforces the multi-level structure of fundamental rights protection in the European legal order. At first blush the logic of the judgment is reminiscent of that of the Bundesverfassungsgericht in Solange II ${ }^{24}$ and in the Bananas judgment. ${ }^{125}$ But in fact the logic applies in reverse, and Strasbourg is showing a deference to Luxembourg which, first, Luxembourg never allows national courts, and second, is perhaps not wholly reassuring. At its core the problem is the differences in jurisdiction and legal culture between Luxembourg and Strasbourg, and the hierarchical relationship (if it exists) between the two. Luxembourg will not tolerate, for example, the German Basic Law reserving to German courts a fundamental rights jurisdiction because Community law must be uniform. Why this should be a less pressing concern for Strasbourg, mutatis mutandis, is not clear. And can it ever be uniform when applied by the two courts? Does this mean lesser human rights protection in the 27 European states contracting parties to the Convention and within the Union and greater in the 19 outside? Or can a higher Union standard (should it exist) flow the other way, so that Community judges are instrumental in shaping the meaning of the Convention as it applies, say, in the Russian Federation?

There is one comforting difference in this comparison: it appears from the Bananas judgment that Karslruhe now requires a general or very significant abnegation by Luxembourg of duty to protect human rights before it will resuscitate its jurisdiction and intervene, ${ }^{126}$ whilst Bosphorus seems to stand for the proposition that the presumption of compliance is rebuttable upon a case by case basis: 'The concept of a presumption of Convention compliance should not be interpreted as excluding a case by case review by this Court of whether there was really a breach of the Convention. ${ }^{127}$ If it discharges this review jurisdiction

\footnotetext{
123 Ibid para 166.

124 BVerfG, 22. Oktober 1986, BVerfGE 73, 339.

125 BVerfG, 7. Juni 2000, BVerfGE 102, 147.

126 Ibid § II(d).

127 Per opinion of Judge Ress para 2.
} 
robustly, there is maybe little to fear. But the entrails are not wholly encouraging. There is a presumption of Convention compatibility which will be rebutted only where the Court of Human Rights finds the protection of Convention rights 'manifestly deficient'. ${ }^{128}$ Does this mean outrageous? And by whose standards? Some would judge Unión de Pequeños Agricultores to be outrageous. It is analogous, and maybe equivalent, to the lines in the sand drawn by the Bundesverfassungsgericht in the Solange I, ${ }^{129}$ subsequently Bananas, ${ }^{130}$ and the qualitatively different Maastricht judgments, ${ }^{131}$ or the 'ekstraordinžre situation' mooted by the Danish Højesteret $^{132}$ which would justify it departing from Community law should the institutions come to exceed the limits 'entrusted' to them ${ }^{133}$ by the Danish law of accession. But these are widely perceived to be judicial nuclear weapons never likely to be deployed. It may be the same for Strasbourg's latent authority. The test would come, and the fireworks begin, should a Luxembourg judgment ever be 'set aside' by Strasbourg. Not only is this procedurally difficult and the outcome difficult to predict, it seems increasingly unlikely ever to happen.

But it is not wholly impossible. The judgment in Bosphorus includes a shot across Luxembourg's bow on matters of review of Community measures in the separate, concurring opinion of Judge Ress, ${ }^{134}$ who is as much a Community lawyer as he is a human rights lawyer:

This judgment demonstrates how important it will be for the European Union to accede to the European Convention of Human Rights in order to make the control mechanism of the Convention complete, even if this judgment has left the so-called M. \& Co. approach far behind. It has accepted the Court's jurisdiction ratione loci, personae and materiae under Article 1 of the Convention, clearly departing from an approach which would declare the European Communities (EC) immune, even indirectly, from any supervision by this Court [...].

[...] The Court has not addressed the question of whether this limited access [of individuals to the Court of Justice] is really in accordance with Article $6 \S 1$ of the Convention and whether the provisions, in particular, of [...] Article [230] should not be interpreted more ex-

128 Bosphorus (n 116) para 156.

129 BVerfG, 29. Mai 1974, BVerfGE 37, 271.

130 BVerfG, 7. Juni 2000 (n 125).

131 BVerfG, 12. Oktober 1993, BVerfGE 89, 155.

132 Dom af 6. april 1998, UfR 1998800.

133 Danmarks Riges Grundlov § 20.

134 There were two separate concurring opinions, the first of a group of six judges (Rozakis, Tulkens, Traja, Botoucharova, Zagrebelsky and Garlicki), the second of Judge Ress. 
tensively in the light of Article $6 \S 1$, a point that was in issue before both the Court of First Instance and the ECJ in the case of JégoQuéré \& Cie SA v Commission and Unión de Pequeños Agricultores $v$ Council. One should not infer from [...] the judgment in the present case that the Court accepts that Article $6 \S 1$ does not call for a more extensive interpretation [...]. The Court's analysis of the 'equivalence' of the protection is a rather formal one [...]. In my view, one can not say for once and for all that, in relation to all Convention rights, there is already such a presumption of Convention compliance because of the mere formal system of protection by the ECJ. ${ }^{135}$

Herein lies some comfort for those who support greater Strasbourg activism and mistrust the human rights jurisprudence of the Community courts. It does not leave Luxembourg the last word. But it makes the practical protection of human rights within the Community/Union little clearer.

Strasbourg will presumably remain steadfast in those cases of Community measures which cannot be brought within Luxembourg's jurisdiction, as it was in Matthews. And it is of key importance to note that this applies in ever widening fields. First, there are extensive tangencies between Convention matters and Union activities under Titles V and VI of the TEU but much of Union activity (and some related Community activity) escapes Luxembourg scrutiny altogether. ${ }^{136}$ If, say, the Council adopts a framework decision under Title VI which is then implemented by a measure of transformation adopted by a national authority in a member state which has not made a declaration under article 35(2) of the TEU, Luxembourg is effectively barred from reviewing it; but in light of Matthews the member state may be called to account before its national courts and, ultimately, Strasbourg. The variable geometry of this - as well as support for the view held by some that Luxembourg is overly deferential to the Community (or here, Union) legislature - is apparent over

135 Opinion of Judge Ress paras 1, 2.

136 See Art 35 TEU, which allows for references to be made to the Court of Justice from national courts on the validity and interpretation of some Title VI measures but only if the relevant member state has made an enabling declaration to that effect under art 35(2), so introducing a degree of 'judicial variable geometry' into the Court's jurisdiction. The necessary declarations have been made by 14 member states - that is, Belgium, the Czech Republic, Germany, Greece, Spain, France, Italy, Luxembourg, Hungary, the Netherlands, Austria, Portugal, Finland and Sweden. This applies mutatis mutandis under Title IV of the EC Treaty (on visas, asylum, immigration and the free movement of persons), art 68 limiting the reference power to courts of final instance and expressly ousting from the jurisdiction of the Court of Justice art 62(1) matters (on abolition of controls on the trans-frontier movement of persons) if they relate to the maintenance of law and order and the safeguarding of internal security. 
the European arrest warrant, ${ }^{137}$ which was given a clean bill of health by the Court of Justice ${ }^{138}$ but has failed to pass human rights muster in the constitutional courts of at least two member states. ${ }^{139}$ The Court of Justice had jurisdiction to consider the validity of the framework decision in Advocaten voor de Wereld because the Belgian Arbitragehof enjoyed the authority to ask the question; this would not be the case for the courts of 13 other member states. Are the courts of those 13 member states bound by, or even entitled to take notice of, the validity of the framework decision as determined in the judgment? Does it mean standards will be higher (or at least different) there, with Strasbourg alone competent to determine its human rights compatibility?

Perhaps even more worrying are the legal obligations emanating from outwith even the Union, and in particular the new, post-cold war activism of the UN Security Council. On substance the Security Council is probably bound in its conduct by the UN Charter, jus cogens, and universal instruments such as, for example, the International Covenant on Civil and Political Rights. ${ }^{140}$ These are worthy enough, but they are in comparison with the Convention and the Charter rudimentary. Do we wish the will of the Security Council to be free of them within Europe? And on simple procedure, who will protect us from the Security Council? Not the Hague, because the individual cannot invoke the jurisdiction of that Court. Not Luxembourg, for, as we now know, the Court of Justice will neither review nor otherwise interfere with the application of a Security Council resolution except insofar as it constitutes a breach of jus cogens. ${ }^{141}$ And not Strasbourg, if it places too much trust in Luxembourg.

The next chapter is likely to involve yet more Treaty-entrenched variable geometry, addressing the Charter itself. At the June 2007 European Council in Brussels which agreed the 'draft IGC mandate' which has breathed life back into the Constitutional Treaty, the United Kingdom secured, as a price of its agreement, the promise of an opt-out from the

137 The 'European arrest warrant' was introduced as a 2002 framework decision (Framework Decision 2002/584/JHA of 13 June 2002 on the European arrest warrant and the surrender procedures between Member States [2002] OJ L190/1) by authority of arts 31(a) and (b) and 34(2)(b) TEU - that is, a Title VI measure.

138 Case C-303/05 Advocaten voor de Wereld $v$ Leden van de Ministerraad (ECJ 3 May 2007).

139 National laws giving effect to the framework decision were struck down by the Trybunal Konstytucyjny (27 kwietnia 2005 r., P 1/05 (Europejski Nakaz Aresztowania)) and the Bundesverfassungsgericht (BVerfG, 18. Juli 2005 (Europäischer Haftbefehl-Beschluß), BVerfGE 113, 273), albeit not for Convention incompatibility but for breaching the human rights guarantees of the Polish constitution and the German Basic Law, respectively.

140 International Covenant on Civil and Political Rights (adopted 16 December 1966, entered into force 23 March 1976) 999 UNTS 171.

141 Case T-306/01 Yusuf $v$ Council and Commission [2005] ECR I-3533. 
Charter, in the form of a protocol to be annexed to the Treaties in the following terms:

1. The Charter does not extend the ability of the Court of Justice, or any court or tribunal of the United Kingdom, to find that the laws, regulations or administrative provisions, practices or action of the United Kingdom are inconsistent with the fundamental rights, freedoms and principles that it reaffirms.

2. In particular, and for the avoidance of doubt, nothing in Title IV of the Charter creates justiciable rights applicable to the United Kingdom except in so far as the United Kingdom has provided for such rights in its national law.

[...]

To the extent that a provision of the Charter refers to national laws and practices, it shall only apply in the United Kingdom to the extent that the rights or principles that it contains are recognised in the law or practices of the United Kingdom. ${ }^{142}$

It has since transpired that, with much less fanfare, Ireland and Poland have secured, and are reserving their positions on, a right to opt out of the Charter in a similar fashion. ${ }^{143}$ Whilst there is still much to play for in the intergovernmental conference, it must be assumed, especially as it "will be conducted under the overall responsibility of the Heads of State or Government', ${ }^{144}$ that the protocol will find its way into the final text.

The next question is, what does it mean? There is the peculiar emphasis upon Title IV of the Charter ('Solidarity'), which deals with social rights such as worker participation, collective bargaining, protection from unfair dismissal, protection in the workplace and social security and social assistance; whilst these are areas of Community authority traditionally anathema to British governments, and this is (indirectly) re-emphasised in article 2 of the protocol, ${ }^{145}$ there is no indication as to

142 Draft Protocol (No 7) on the Application of the Charter of Fundamental Rights to the United Kingdom arts 1 and 2.

143 'State gets opt-out clause in EU rights charter' The Irish Times (Dublin 26 June 2007) 1. This is substantiated by a footnote in the Presidency Conclusions of the Brussels European Council (Doc 11177/07 Concl 2 Annex 1 point 5 fn 20) that 'two [unidentified] delegations reserved the right to join in this Protocol'.

144 'Presidency Conclusions' (ibid) para 12.

145 Art 2 purports to restrict the application in the United Kingdom of Charter provisions informed by national laws and practices, but virtually all of these are to be found in Title IV; that is, art 27 (worker participation), art 28 (collective bargaining), art 30 (unjustified dismissal), art 34 (social security and social assistance), art 35 (health care) and art 36 (access to services of general economic interest). The only exceptions are art 9 (right to marry), art 10 (conscientious objection), art 14 (education) and art 16 (the right to conduct a business). 
why they are to enjoy such pre-eminence in the protocol. If the intention is merely to emphasise Title IV, the pudding may have been over-egged: the link with the first paragraph is 'for the avoidance of doubt', rather than the more common (at least in British style) 'for greater certainty', sometimes with the added emphasis of 'but not so as to restrict the generality of the foregoing', and it may result in Title IV matters being severed from the rest of the Charter and the first paragraph being read down to that extent; it mimics the opt-out of the Social Protocol and Agreement the United Kingdom 'enjoyed' from 1993 to 1998, ${ }^{146}$ if through the back door, and would in any event be largely Convention compatible, because it is more Charter of Fundamental Social Rights than Convention territory. If taken to a wider amplitude, the Charter will not 'extend' (étend; ausdehnen) the 'abilities' (faculté; Befugnis) of competent courts across the fields of Charter application. These are provisions which betray either ignorance of legal terminology ('ability' of a court?) and logic (extend whence?) or an unfathomable intent. But read generously, their intention, and maybe their effect, is to oust from the jurisdiction of the Court of Justice and of British courts the power to measure British laws against the Charter when, necessarily (because the Charter is of no wider application), they implement Union law. If so it may represent a significant own goal, for if the Court of Justice is deprived of it its normal task of review of national legislation for Charter compatibility, it may be inviting others to fill the gap, leaving British law bared to Convention control by Strasbourg by default - more Matthews than Bosphorus - and, reverting back to Judge Wildhaber's détriplement fonctionnel, ${ }^{147}$ in the hands of national courts unmoderated by Luxembourg deference; and since the incorporation of the Convention into UK law in $1998,{ }^{148}$ British courts have shown themselves not to be reticent in using it.

In the end the protocol may apply to the United Kingdom alone, or it may within the IGC become infectious, in which case any achievement in 'recognising' the Charter and its legally binding force is diminished. But its important may be more political: doubtless the opt-out will meet with the approval of the British House of Commons, and would appeal to the British people in the event of the referendum once promised but now withheld. It is not clear the Irish would be so sanguine: it would be ironic

146 By virtue of agreement reached at Maastricht the United Kingdom was absolved of adherence to much of Community social legislation. The mechanism for giving effect to this opt-out was contained in a protocol to the EC Treaty (the Protocol on Social Policy). Following agreement with the Labour government elected in 1997, the legislation was extended to the United Kingdom and the Social Protocol was subsequently deleted from the Treaty by the Treaty of Amsterdam with its entry into force in 1999.

147 See $\mathrm{n} 1$.

148 Human Rights Act 1998. 
if the Constitutional Treaty, having after a two year 'period of reflection' emulated Lazarus in the form of the Reform Treaty, were again to fall upon the popular will, in the (compulsory) Irish referendum prior to ratification $^{149}$ owing to efforts by the government to withhold from the Irish people Charter rights enjoyed in (most) other member states.

149 Alone amongst the member states (with the possible exception of Slovakia), Irish constitutional law requires a popular referendum be held prior to ratification by the State of a treaty significantly amending a treaty upon which the Union is founded; see Crotty $v$ An Taoiseach [1987] IR 713 (SC). 